\title{
Strategic Container Ports Competitiveness Analysis in West Africa Using Data Envelopment Analysis (DEA) Model
}

\author{
Bomboma Kalgora \\ School of Economics and Management, Shanghai Maritime University, Shanghai, China \\ Email: research.kb@outlook.com
}

How to cite this paper: Kalgora, B. (2019) Strategic Container Ports Competitiveness Analysis in West Africa Using Data Envelopment Analysis (DEA) Model. Open Journal of Business and Management, 7, 680692.

https://doi.org/10.4236/ojbm.2019.72046

Received: March 2, 2019

Accepted: April 5, 2019

Published: April 8, 2019

Copyright $\odot 2019$ by author(s) and Scientific Research Publishing Inc. This work is licensed under the Creative Commons Attribution International License (CC BY 4.0). http://creativecommons.org/licenses/by/4.0/

\begin{abstract}
This study presents a competitiveness analysis of five strategic container ports in West Africa using the DEA model Windows I-C method. This method takes into account the different changes in these ports efficiency and performance using a window length of 3 over the years 2005 to 2016. The model is used to provide a ranking of the efficient strategic ports in the region. Efficient ports promote trade growth by empowering a country's imports and exports. The ranking and competitiveness of a port are evaluated based on its efficiency compared to others in its group. From the one output and the seven input variables selected, the results reveal the port of Tema to be the most competitive in the West Africa with $95 \%$ production average efficiency score, then followed respectively by Lagos, Abidjan, Lomé and Cotonou port.
\end{abstract}

\section{Keywords}

Container Ports, Competitiveness, Efficiency, Data Envelopment Analysis, West Africa

\section{Introduction}

The international trade at the present time, is commonplace and goods are rarely consumed where they are produced. About $90 \%$ of international trade is done by sea [1], and the sea-leg transportation needs seaports, also commonly called sea gateways. They are nodes or interfaces platform connecting with the land-leg freight movement. Standing at the interface of sea and its inland transportation, the West African ports play major role in international trade for the region. These are crucial nodes determining the wellness of the international trade with the region landlocked countries. Despite investments made and the region's 
ports authorities' efforts to improve the container throughput in terminals, many of these sea gateways are by far the least dynamic in the world [2]. The sea ports of the region compete with each other for the landlocked countries markets as well as the internal markets of host countries.

These developing countries' ports unproductiveness, assessed by global standard, find their origin in inadequate investments and facilities, triggering congestion, long delays and dwell time, thus affecting port competitiveness in terms of import and export prices. In the case of the five West Africa selected ports, they are of high importance as they have international status with much considerable annual container throughput. They are also better positioned in servicing the markets of same landlocked countries namely Burkina Faso, Mali, and Niger. This creates a tense competition in the regional port sector.

This paper therefore aims to examine the relative efficiency and port competitiveness of following strategic sea ports in West Africa, the port of Abidjan, the port of Tema, the port of Cotonou, the port of Lagos and the port of Lomé. These sea gateways are strategic in the sense that they are counted among the regional leading ports and, added to the fact that they compete for the same markets.

The remainder of this study is organized in the following way. Section 2, presents the research theoretical basis on the topic of ports competitiveness. Section 3, introduces the data source and the methodology adopted, then Section 4 presents and discusses the empirical results of the five studied strategic West African container ports. The paper concludes the study in Section 5.

\section{Literature Review}

A careful literature review has disclosed numerous aspects that occupies port research involving port competition [3]. One of the earliest references to port competition is author's [4] definition in which he conceptualizes and differentiates between four different levels of port competition. These are: 1) competition between port undertakings (determined by factors of production), 2) competition between ports, 3) competition between port clusters and 4) competition between ranges. Therefore, factors that affect a port's competitive position can be grouped into two categories; the factors that are within the port's capacity to control and other factors outside the bounds of the port's control. Controllable factors which are the focus of this study, may include efficiency and productivity, or port charges and services. On the other hand, non-controllable factors may include local market size, global transportation environment and national transportation policies. Also, the authors [5] explain three levels of container ports competition. The first level is intra-port competition which occurs between terminal operators at a specific port. The second level is inter-port competition between operators whereby terminal operators compete with other operators located in other national or regional ports serving the same hinterland. The third level is inter-port competition between ports authorities directed towards, as 
authors [6] put it, "the utility mission of seaports".

Generally, the competitive position of a container port is determined by its level of differentiation from other competing ports. The port must offer a level of service demanded by port users for specific trade route or within a specific geographic region that outweighs that of its competitors. A situation may exist whereby a particular port may be solely in the position to provide access to a particular hinterland market thereby giving it total monopoly in the market. On the other hand, a situation may also exist whereby many ports within a region may be able to provide access to a common hinterland market thereby creating fierce competition. Port services are thus provided on competitive basis. Due to the competitive nature of the evolving port sector through improvements, etc. [7]. Competitive advantage in the port industry is very much a matter of internal port influences as external environment influences [8]. Therefore, there is a need to assess the efficiency ratio of the several ports which are competing.

Emphasizing on both second levels of port competition as individually identified by authors [4] and [5], this study attempts to examine the competitiveness of West African strategic container ports using the mathematical programming model, Data Envelopment Analysis (DEA) Window I-C. The model maps out a production frontier based on information on inputs and outputs. The application of the DEA technique to the port industry is not new. Different variations of the DEA techniques have been used to analyze port productivity and competitiveness in various regions worldwide [9], comparative analysis of models [10], port investment and efficiency [11], operational efficiency [12]. Unlike the port performance indicators developed by UNCTAD [13], the advantage of DEA is that multiple inputs and outputs can be added to the model, and it therefore has the capability of providing an overall evaluation of port performance [14]. Actually, there is no consensus in the selection of inputs and outputs variables [15].

\section{Data and Methodology}

\subsection{Data and Variables Specification}

The study covers a period of 12 years from 2005 to 2016. The paper selected the 5 strategic countries container ports in the West African region. These container ports are identified as Decision Making Units (DMUs), and are shown in Table 1

Table 1. DEA decision making units.

\begin{tabular}{ccc}
\hline S/N & Country & Ports Name \\
\hline 1 & Cote d'Ivoire & Port of Abidjan \\
2 & Benin & Port of Cotonou \\
3 & Nigeria & Port of Lagos \\
4 & Togo & Port of Lomé \\
5 & Ghana & Port of Téma \\
\hline
\end{tabular}

Source: Processed by the Author. 
Table 2. DEA inputs and output variables.

\begin{tabular}{|c|c|c|}
\hline & Variables & Measurement \\
\hline & Quay Length & Total quay length in meters $(\mathrm{m})$ \\
\hline & Terminal Area & Total size of terminal in hectare $(\mathrm{Ha})$ \\
\hline & Quayside Cranes & Total number of quayside cranes \\
\hline \multirow[t]{4}{*}{ Inputs } & Yard Gantry Cranes & Total number of Gantry Cranes \\
\hline & Reach Stackers & Total number of Reach Stackers \\
\hline & Draught & Depth of Container Terminals (m) \\
\hline & Container Throughput Limit & Port Terminal Handling Capacity (TEU) \\
\hline Outputs & Container Throughput & Annual Cargo Throughput (TEU) \\
\hline
\end{tabular}

Source: Processed by the Author.

for this study. They practically possess similar operational measures.

The competitive analysis of these ports, is carried out using the DEA Window I-C method. The DEA efficiency ratings can be a useful tool for port managers and for researchers, providing a deeper insight into ports performances [16]. Researches revealed an absence of consensus in the choice of the types of variables (inputs and outputs) used in the DEA model [15]. Plainly, authors [17] emphasize that the precise choice of inputs and output variables is critical to the evaluation of ports container terminals and undefined variables may lead to misleading conclusions about port evaluation.

The research therefore intends to assess the operational efficiencies of the selected DMUs. Seven input variables and one output variable are selected, and the standard container size or TEU is used with regards to the output variable (see Table 2). In order to be consistent with the production framework, like in previous studies applying DEA method [12] [18], this research uses proxies to evaluate the ports competitiveness through the labour and capital inputs. As for the labour inputs, the number of handling equipment's such as quayside cranes, yard gantry cranes and reach stackers are used as measurement proxy. The quay length, the container throughput limit, the terminal area, and the draught are selected as a proxy for capital, whereas, the container throughput is used as the only output in this study.

The inputs variables data listed in Table 2 (see data in Appendix 1) were compiled from national and regional ports authorities association such as the Port Management Association of West \& Central Africa [19] while the output variable of each of the five DMUs, the container throughput (see data in Appendix 2), is obtained from international institutions such as the World Bank [20], and for accuracy purpose, are double checked with other regional institutions namely the ECOWAS, and the WAEMU.

\subsection{DEA Mathematical Formulation and Objective Function}

The linear programming technique is used to find the set of coefficients ( $u$ 's and 
$v^{2} s$ ) that will give the highest possible efficiency ratio of outputs to inputs for the service unit being evaluated [21].

$D M U_{j}=$ service unit number $j$

$j=$ number of decision making units (DMU) being compared in the DEA analysis.

$\theta=$ efficiency rating of the decision making unit being evaluated by DEA

$y_{i j}=$ amount of output $r$ used by service unit $j$

$X_{i j}=$ amount of input $r$ used by service unit $j$

$i=$ number of inputs used by the DMUs

$r=$ number of outputs generated by the DMUs

$u_{r}=$ coefficient or weight assigned by DEA to output $r$

$v_{i}=$ coefficient or weight assigned by DEA to input $i$

The function is subject to the constraint that when the same set of $u$ and $v$ coefficients is applied to all other service units being compared, no service unit (DMUs) will be more than efficient than 1. Scholars [22] suggested the following mathematical programming for estimating the relative efficiency score of a particular DMU $j$ among similar $n$ entities being evaluated.

$$
\begin{gathered}
D M U_{j}=\frac{u_{1} y_{1 j}+u_{2} y_{2 j}+\cdots+u_{r} y_{r j}}{v_{1} x_{1 j}+v_{2} x_{2 j}+\cdots+v_{i} x_{i j}}=\frac{\sum_{r=1}^{s} u_{r} y_{r j}}{\sum_{i=1}^{m} v_{i} x_{i j}} \leq 1, j=1, \cdots, n \\
u_{r}, \cdots, u_{s}>0 \text { and } v_{i}, \cdots, v_{m} \geq 0 ; r=1, \cdots, s ; i=1, \cdots, m
\end{gathered}
$$

To solve the fractional mathematical programming problem, Equation (1) has been transformed into a linear programming model written below:

$$
\begin{aligned}
\max & \sum_{r=1}^{S} u_{r} y_{r o} \\
\text { S.t. } & \sum_{r=1}^{S} u_{r} y_{r j}-\sum_{i=1}^{m} v_{i} x_{i j} \leq 0, j=1, \cdots, n \\
& \sum_{i=1}^{m} v_{i} x_{i 0}=1 \\
& u_{r}, v_{i} \geq 0
\end{aligned}
$$

As earlier mentioned, the DEA model Windows I-C gives an efficiency value close to one, which can be expressed in percentage in order to provide accordingly a ranking among the competitive ports by highlighting the most efficient ones.

\section{Empirical Results}

\subsection{Data Analysis and Description}

The characteristics of the variables used to estimate the relative competitiveness of the selected ports are presented in Table 3. It shows the statistics employed in the DEA excel solver and this includes; the Maximum, the Minimum, the Average and the Standard deviations.

Based on the graph in Figure 1, it can be seen that the Port of Lagos has the highest number of container throughput in this group. Nevertheless, there are 
Table 3. Descriptive statistics for inputs and outputs variables in year 2016.

\begin{tabular}{ccccccccc}
\hline & \multicolumn{8}{c}{ Inputs } \\
Statistics & $\begin{array}{c}\text { Quay Length } \\
(\mathrm{m})\end{array}$ & $\begin{array}{c}\text { Terminal } \\
\text { Area (Ha) }\end{array}$ & $\begin{array}{c}\text { Quayside } \\
\text { Cranes }\end{array}$ & $\begin{array}{c}\text { Yard Gantry } \\
\text { Cranes }\end{array}$ & $\begin{array}{c}\text { Reach } \\
\text { Stackers }\end{array}$ & $\begin{array}{c}\text { Draught } \\
(\mathrm{m})\end{array}$ & $\begin{array}{c}\text { Annual Container } \\
\text { Throughput Limit (TEU) }\end{array}$ & $\begin{array}{c}\text { Container } \\
\text { Throughput (TEU) }\end{array}$ \\
\hline Max & 1752 & 42 & 14 & 16 & 23 & 14.5 & $2,000,000$ & $1,335,470$ \\
Min & 575 & 14 & 6 & 10 & 14 & 11.5 & 700,000 & 333,000 \\
Mean & 1027.4 & 25.4 & 9.4 & 13 & 17 & 12.5 & $1,280,000$ & $824,214.6$ \\
St. Dev. & 435.080 & 11.092 & 3.072 & 2 & 3.162 & 1.265 & $444,522.215$ & $324,729.291$ \\
\hline
\end{tabular}

Source: Processed by the Author.

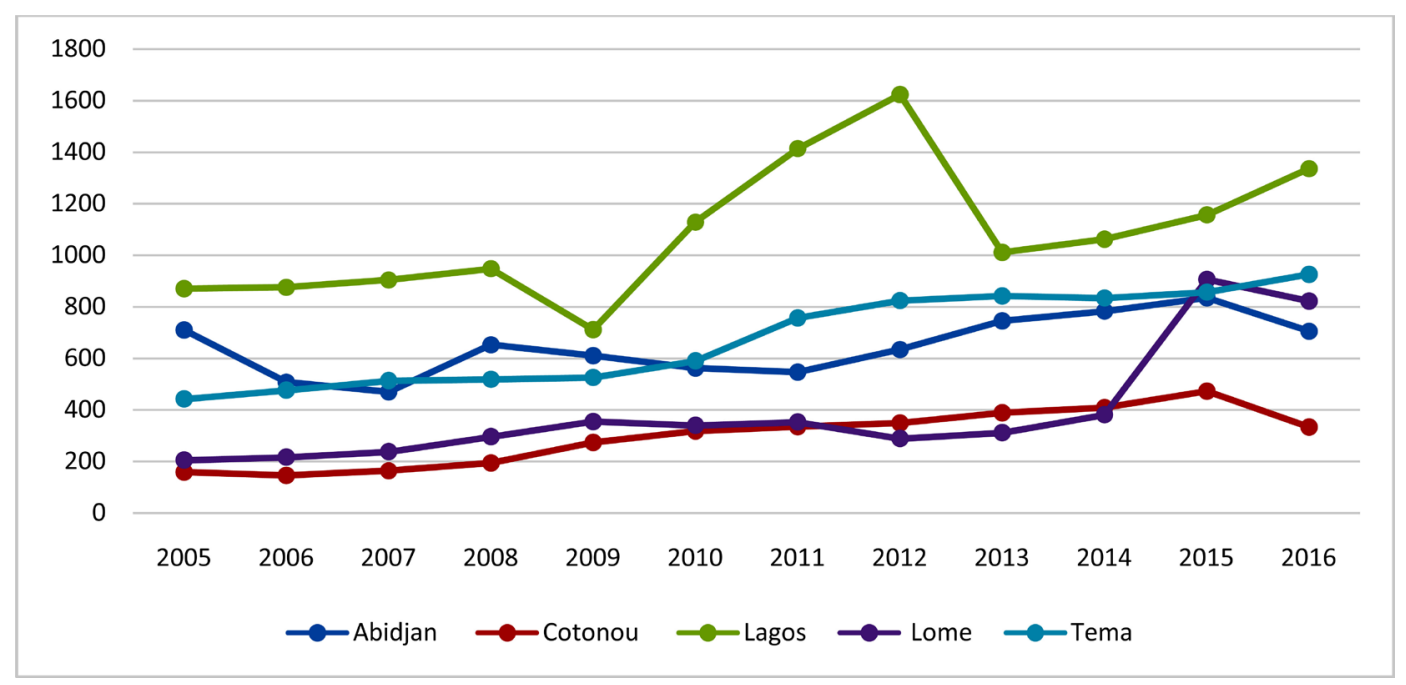

Source: Processed by the Author.

Figure 1. Container Throughput Trend TEU's in Thousands, from year 2005-2016.

noticeable sharp decrease of throughput from 2008 to 2009 of about $25 \%$, and 2012 to 2013 of about 38\%. 2012 marks its highest throughput with 1.62 Million TEUs throughout the study period. All other 4 ports showed less variation throughout the study period, with the Port of Lomé marking a sharp throughput growth of $138 \%$ from 2014 to 2015 . This upsurge is explained by the Lomé Container Terminal (LCT), a terminal dedicated to container transhipment, which entered officially into operation in 2014. The ports of Abidjan, Cotonou and Lomé saw a reduction of throughput from 2015 to 2016 contrary to the other two ports of the study. The port of Tema saw a constant increase in term of throughput over time.

\subsection{Results Interpretation}

From the analysis in Table 4, the researcher notes that despite being the smallest port, the port of Tema is practically the most efficient port among the selected ports under study. It scored a production average efficiency of $95 \%$ over a period of time observed with variables input in term of quay length, terminal area, and draught. The ports of Lagos and Abidjan also obtained a high efficiency score of 
Table 4. DEA efficiencies of five selected ports from year 2005-2016, using a three-year window.

\begin{tabular}{|c|c|c|c|c|c|c|c|c|c|c|c|c|c|c|}
\hline & 2005 & 2006 & 2007 & 2008 & 2009 & 2010 & 2011 & 2012 & 2013 & 2014 & 2015 & 2016 & Average & C-Average \\
\hline \multirow{10}{*}{$\begin{array}{l}\text { Port of } \\
\text { Abidjan }\end{array}$} & 1 & 0.7143 & 0.6610 & & & & & & & & & & 0.7917 & \\
\hline & & 0.7774 & 0.7194 & 1 & & & & & & & & & 0.8322 & \\
\hline & & & 0.7194 & 1 & 0.9354 & & & & & & & & 0.8849 & \\
\hline & & & & 0.9252 & 0.8654 & 0.7964 & & & & & & & 0.8623 & \\
\hline & & & & & 0.6908 & 0.6357 & 0.6186 & & & & & & 0.6484 & \\
\hline & & & & & & 0.6357 & 0.6186 & 0.5367 & & & & & 0.5970 & \\
\hline & & & & & & & 0.6186 & 0.5367 & 0.6308 & & & & 0.5954 & \\
\hline & & & & & & & & 0.6695 & 0.7869 & 0.8271 & & & 0.7612 & \\
\hline & & & & & & & & & 0.9515 & 1 & 1 & & 0.9838 & \\
\hline & & & & & & & & & & 0.9567 & 1 & 0.8440 & 0.9336 & 0.7891 \\
\hline \multirow{10}{*}{$\begin{array}{l}\text { Port of } \\
\text { Cotonou }\end{array}$} & 0.5009 & 0.4599 & 0.5169 & & & & & & & & & & 0.4926 & \\
\hline & & 0.4553 & 0.5118 & 0.6074 & & & & & & & & & 0.5248 & \\
\hline & & & 0.5046 & 0.5989 & 0.8433 & & & & & & & & 0.6489 & \\
\hline & & & & 0.5335 & 0.7512 & 0.8722 & & & & & & & 0.7190 & \\
\hline & & & & & 0.5857 & 0.6800 & 0.7188 & & & & & & 0.6615 & \\
\hline & & & & & & 0.6800 & 0.7188 & 0.4563 & & & & & 0.6184 & \\
\hline & & & & & & & 0.7188 & 0.4554 & 0.5079 & & & & 0.5607 & \\
\hline & & & & & & & & 0.6219 & 0.6936 & 0.7290 & & & 0.6815 & \\
\hline & & & & & & & & & 0.7263 & 0.7633 & 0.8830 & & 0.7909 & \\
\hline & & & & & & & & & & 0.7230 & 0.8364 & 0.5899 & 0.7164 & 0.6415 \\
\hline \multirow{10}{*}{$\begin{array}{l}\text { Port of } \\
\text { Lagos }\end{array}$} & 0.9629 & 0.9684 & 1 & & & & & & & & & & 0.9771 & \\
\hline & & 0.9236 & 0.9537 & 1 & & & & & & & & & 0.9591 & \\
\hline & & & 0.9537 & 1 & 0.7503 & & & & & & & & 0.9013 & \\
\hline & & & & 0.8398 & 0.6300 & 1 & & & & & & & 0.8233 & \\
\hline & & & & & 0.5029 & 0.7983 & 1 & & & & & & 0.7671 & \\
\hline & & & & & & 0.7983 & 1 & 1 & & & & & 0.9328 & \\
\hline & & & & & & & 1 & 1 & 0.6228 & & & & 0.8743 & \\
\hline & & & & & & & & 1 & 0.6228 & 0.6545 & & & 0.7591 & \\
\hline & & & & & & & & & 0.8742 & 0.9188 & 1 & & 0.9310 & \\
\hline & & & & & & & & & & 0.7955 & 0.8658 & 1 & 0.8871 & 0.8812 \\
\hline \multirow{6}{*}{$\begin{array}{l}\text { Port of } \\
\text { Lome }\end{array}$} & 0.5947 & 0.6275 & 0.6914 & & & & & & & & & & 0.6379 & \\
\hline & & 0.6188 & 0.6818 & 0.8487 & & & & & & & & & 0.7164 & \\
\hline & & & 0.6711 & 0.8353 & 1 & & & & & & & & 0.8355 & \\
\hline & & & & 0.7417 & 0.8879 & 0.8513 & & & & & & & 0.8270 & \\
\hline & & & & & 0.6941 & 0.6655 & 0.6907 & & & & & & 0.6834 & \\
\hline & & & & & & 0.6655 & 0.6907 & 0.4504 & & & & & 0.6022 & \\
\hline
\end{tabular}




\begin{tabular}{|c|c|c|c|c|c|c|c|c|c|c|c|c|c|c|}
\hline & & & & & & & \multirow[t]{4}{*}{0.6907} & 0.4504 & \multicolumn{4}{|l|}{0.4863} & \multicolumn{2}{|l|}{0.5425} \\
\hline & & & & & & & & 0.6463 & 0.6978 & 0.8531 & & & 0.7324 & \\
\hline & & & & & & & & & 0.7154 & 0.7644 & 1 & & 0.8266 & \\
\hline & & & & & & & & & & 0.7644 & 1 & 0.9072 & 0.8905 & 0.7294 \\
\hline \multirow{10}{*}{$\begin{array}{c}\text { Port of } \\
\text { Tema }\end{array}$} & 0.8614 & 0.9284 & 1 & & & & & & & & & & 0.9299 & \\
\hline & & 0.9192 & 0.9901 & 1 & & & & & & & & & 0.9698 & \\
\hline & & & 0.9762 & 0.9860 & 1 & & & & & & & & 0.9874 & \\
\hline & & & & 0.8783 & 0.8908 & 1 & & & & & & & 0.9230 & \\
\hline & & & & & 0.6945 & 0.7797 & 1 & & & & & & 0.8247 & \\
\hline & & & & & & 0.7797 & 1 & 1 & & & & & 0.9266 & \\
\hline & & & & & & & 1 & 0.9789 & 1 & & & & 0.9930 & \\
\hline & & & & & & & & 0.9789 & 1 & 0.9902 & & & 0.9897 & \\
\hline & & & & & & & & & 0.9826 & 0.9730 & 1 & & 0.9852 & \\
\hline & & & & & & & & & & 0.9004 & 0.9254 & 1 & 0.9420 & 0.9471 \\
\hline Average & 0.7840 & 0.7393 & 0.7701 & 0.8530 & 0.7815 & 0.7759 & 0.8056 & 0.7188 & 0.7533 & 0.8409 & 0.9511 & 0.8682 & & \\
\hline
\end{tabular}

Source: Processed by the Author.

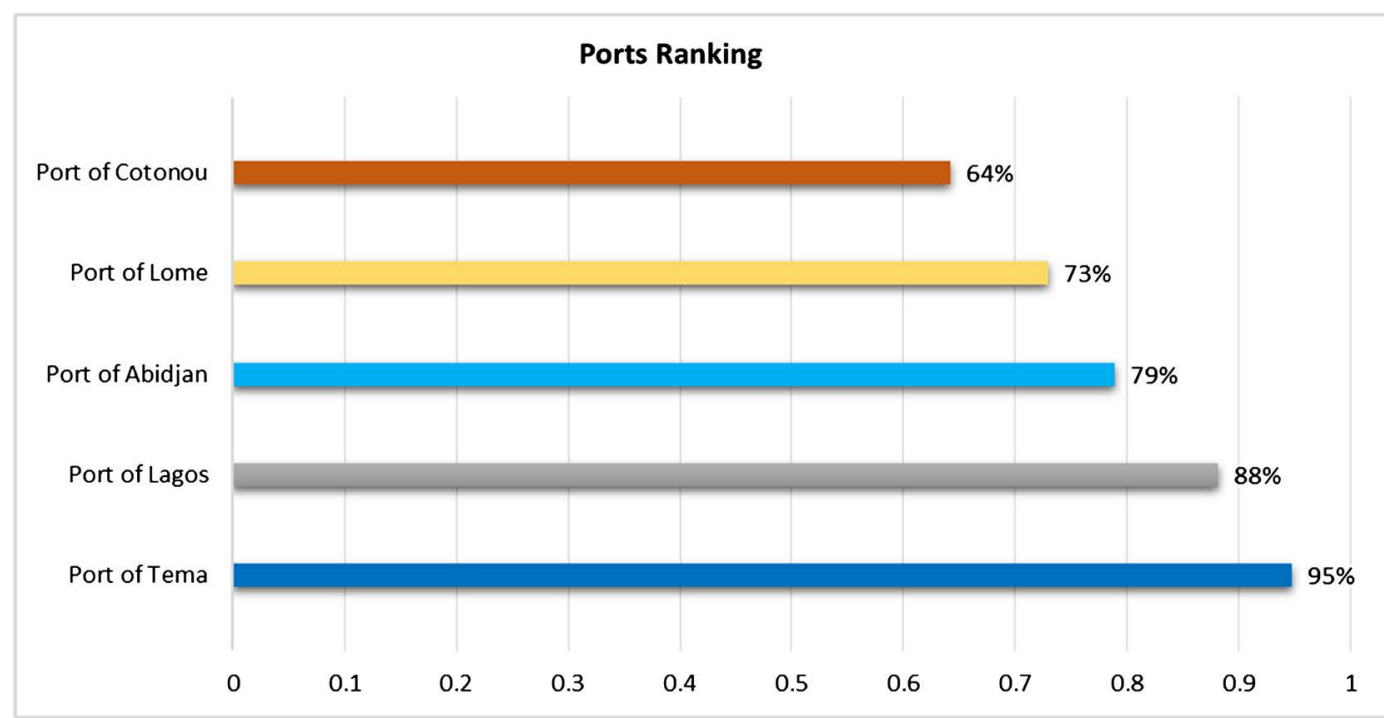

Source: Processed by the Author

Figure 2. Port efficiency ranking.

$88 \%$ and $79 \%$ respectively. However, the port of Lomé despite its advantages in terms of quay length, quayside cranes, reach stackers and draught, scored a lower average efficiency of $73 \%$; and bringing up the rear, the port of Cotonou which showed the lowest performance with an average efficiency score of $64 \%$.

The port of Lagos remains the second largest after the Port of Lomé, in term of size and the first in term of throughput with over 1 million TEU's. Nevertheless, the analysis denotes throughout time the port of Tema (95\%) as the most effi- 
cient port among the selected DMUs (see Figure 2). The port of Lagos comes in second position with an average efficiency of $88 \%$, followed by the port of Abidjan with 79\%. The port of Lomé scores $73 \%$, with the port of Cotonou being the least in term of efficiency with and average score of $64 \%$.

Ports play a critical role in economies of many nations, and the countries in the West African region are not excluded. The five selected West African ports of this study are of high importance as they have an international status with much considerable container throughput. They are also servicing markets of same landlocked countries namely Burkina Faso, Mali, and Niger. Hence, leading to a fierce port competitiveness in the region. For the purpose of the competitiveness study, this research involved the use of a model and methodology to attain rigorous and reliable results. In this regard, the Data Envelopment Analysis (DEA) model was used to evaluate the efficiency and competitiveness of these five strategic ports' region.

\section{Conclusions}

The West African port landscape has evolved rapidly since the turn of the century despite a slow start in adjusting to the requirements of modern shipping liners and containerized trade. Out of the twelve West Africa ports, the present study measured the relative efficiency and competitiveness of five major commercial ports (Abidjan, Cotonou, Lagos, Lomé and Tema). The selection of these ports was in relation to their proximity to the Port of Lomé.

For the purpose of the competitiveness comparative study between these strategic West African ports, the research made use of the Data Envelopment Analysis (DEA), a technique used in port sector. Seven inputs variables were used, annual container throughput limit, draught, reach stackers, yard gantry cranes, quayside cranes, terminal area and quay length, with one output variable container throughput. Based on the DEA model results, the study showed the port of Tema to be the most efficient despite being the smallest port among the ports under study. It was followed by Lagos the first in the region in term of throughput, then the port of Abidjan. The port of Lomé came in the fourth position despite being the largest in terms of size among the studied ports, while the port of Cotonou occupied the last position.

\section{Conflicts of Interest}

The author declares no conflicts of interest regarding the publication of this paper.

\section{References}

[1] Kalgora, B. and Christian, T.M. (2016) The Financial and Economic Crisis, Its Impacts on the Shipping Industry, Lessons to Learn: The Container-Ships Market Analysis. Open Journal of Social Sciences, 4, 38-44. https://doi.org/10.4236/jss.2016.41005

[2] United States International Trade Commission (2009) Sub-Saharan Africa: Effects 
of Infrastructure Conditions on Export Competitiveness. US International Trade Commission, Third Annual Report, Washington DC.

[3] Lam, J. and Yap, W. (2011) Container Port Competition and Complementarity in Supply Chain Systems: Evidence from the Pearl River Delta. Maritime Economics \& Logistics, 13, 102-120. https://doi.org/10.1057/mel.2011.5

[4] Verhoeff, J. (1981) Zeehavenconcurrentie: Overheidsproductie van havendiensten. Vervoersen haveneconomie: Tussen actie en abstractie. Leiden, Stenfert Kroese, 181-202.

[5] Van de Voorde, E. and Winkelmans, W. (2002) A General Introduction to Port Competition and Management. In: Huybrechts, M., et al., Eds., Port Competitiveness, De Boeck, Antwerp, 1-6.

[6] Meersman, H., Van de Voorde, E. and Vanelslander, T. (2010) Port Competition Revisited. Review of Business and Economics, 2, 210-232.

[7] Poitras G., Tongzon, J. and Li, H. (1996) Measuring Port Efficiency: An Application of Data Envelopment Analysis. http://www.bus.sfu.ca/homes/poitras/PORTS2.pdf

[8] Haezendonck, E. (2001) Essays on Strategy Analysis for Seaports. Garant Publishers, Leuven.

[9] Barros, C.P. and Athanassiou, M. (2004) Efficiency in European Seaports with DEA: Evidence from Greece and Portugal. Maritime Economics and Logistics, 6, 122-140. https://doi.org/10.1057/palgrave.mel.9100099

[10] Cullinane, K.P., Wang, T.F., Song, D.W. and Ji, P. (2005) A Comparative Analysis of DEA and SFA Approaches to Estimating the Technical Efficiency of Container Ports. Transportation Research A: Policy and Practice, 40, 354-374.

[11] Garcia-Alonso, L. and Martin-Bofarull, M. (2007) Impact of Port Investment on Efficiency and Capacity to Attract Traffic in Spain: Bilbao versus Valencia. Maritime Economics and Logistics, 9, 254-267. https://doi.org/10.1057/palgrave.mel.9100183

[12] Anguibi, C.F.C. (2015) Analyzing the Operational Efficiency of Container Ports in Sub-Saharan Africa. Open Journal of Social Sciences, 3, 10-17. https://doi.org/10.4236/jss.2015.310002

[13] UNCTAD (1976) Port Performance Indicators. United Nations Conference on Trade and Development, New York.

[14] Wang, T.F., Song, D.W. and Cullinane, K. (2003) Container Port Production Efficiency: A Comparative Study of DEA and FDH Approaches. Journal of the Eastern Asia Society for Transportation Studies, 5, 698-713.

[15] Tongzon, J. (2001) Efficiency Measurement of Selected Australian and Other International Ports Using Data Envelopment Analysis. Transportation Research Part A: Policy and Practice, 35, 107-122. https://doi.org/10.1016/S0965-8564(99)00049-X

[16] Roll, Y. and Hayuth, Y. (2006) Port Performance Comparison Applying Data Envelopment Analysis (DEA).

[17] Cullinane, K.P. and Wang, T.-F. (2006) The Efficiency of European Container Ports: A Cross-Sectional Data Envelopment Analysis. International Journal of Logistics: Research and Applications, 9, 19-31. https://doi.org/10.1080/13675560500322417

[18] Munisamy, S. and Singh, G. (2011) Benchmarking the Efficiency of Asian Container Ports. African Journal of Business Management, 5, 1397-1407.

[19] PMAWCA (2017). http://www.agpaoc-pmawca.org/ 
[20] https://data.worldbank.org/

[21] Sherman, H.D. and Zhu, J. (2006) Data Envelopment Analysis Explained. Service Productivity Management Improving Service Performance using Data Envelopment Analysis (DEA), $328 \mathrm{p}$.

[22] Charnes, A., Cooper, W.W. and Rhodes, E. (1978) Measuring the Efficiency of Decision Making Units. European Journal of Operational Research, 2, 429-444.

https://doi.org/10.1016/0377-2217(78)90138-8 


\section{Appendices}

\section{Appendix 1: Data Inputs and Output Variables}

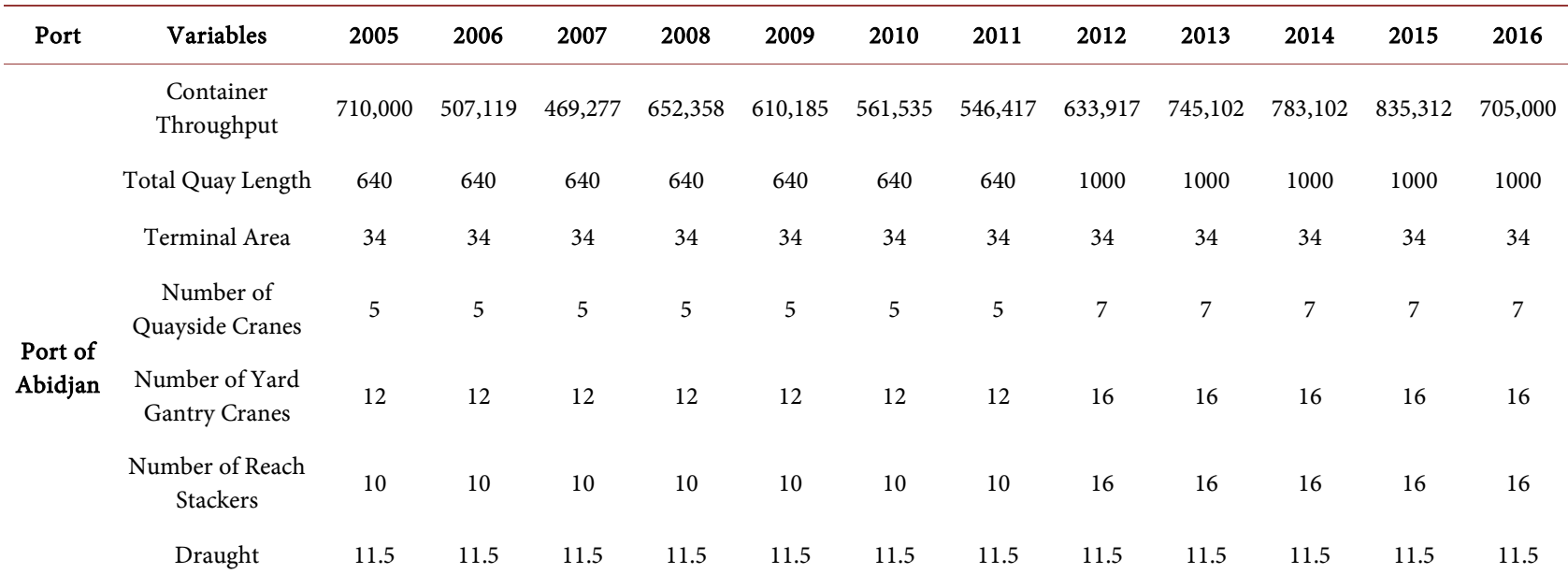

Annual Container

Throughput Limit

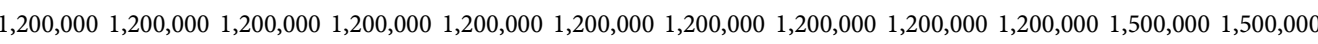

\begin{tabular}{|c|c|c|c|c|c|c|c|c|c|c|c|}
\hline $\begin{array}{l}\text { Container } \\
\text { Throughput }\end{array}$ & 158201 & 145230 & 163240 & 193745 & 272820 & 316744 & 334798 & 348190 & 388341 & 408146 & 472154 \\
\hline
\end{tabular}

$\begin{array}{lllllllllll}\text { Total Quay Length } \quad 400 & 400 & 400 & 400 & 400 & 400 & 400 & 600 & 600 & 600 & 600\end{array}$

$\begin{array}{lllllllllllll}\text { Terminal Area } & 14.5 & 14.5 & 14.5 & 14.5 & 14.5 & 14.5 & 14.5 & 14 & 14 & 14 & 14 & 14\end{array}$

Number of

Quayside Cranes

Port of

Cotonou

Number of Yard

Gantry Cranes

Number of Reach Stackers

Draught

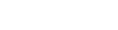

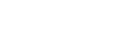




\section{Continued}

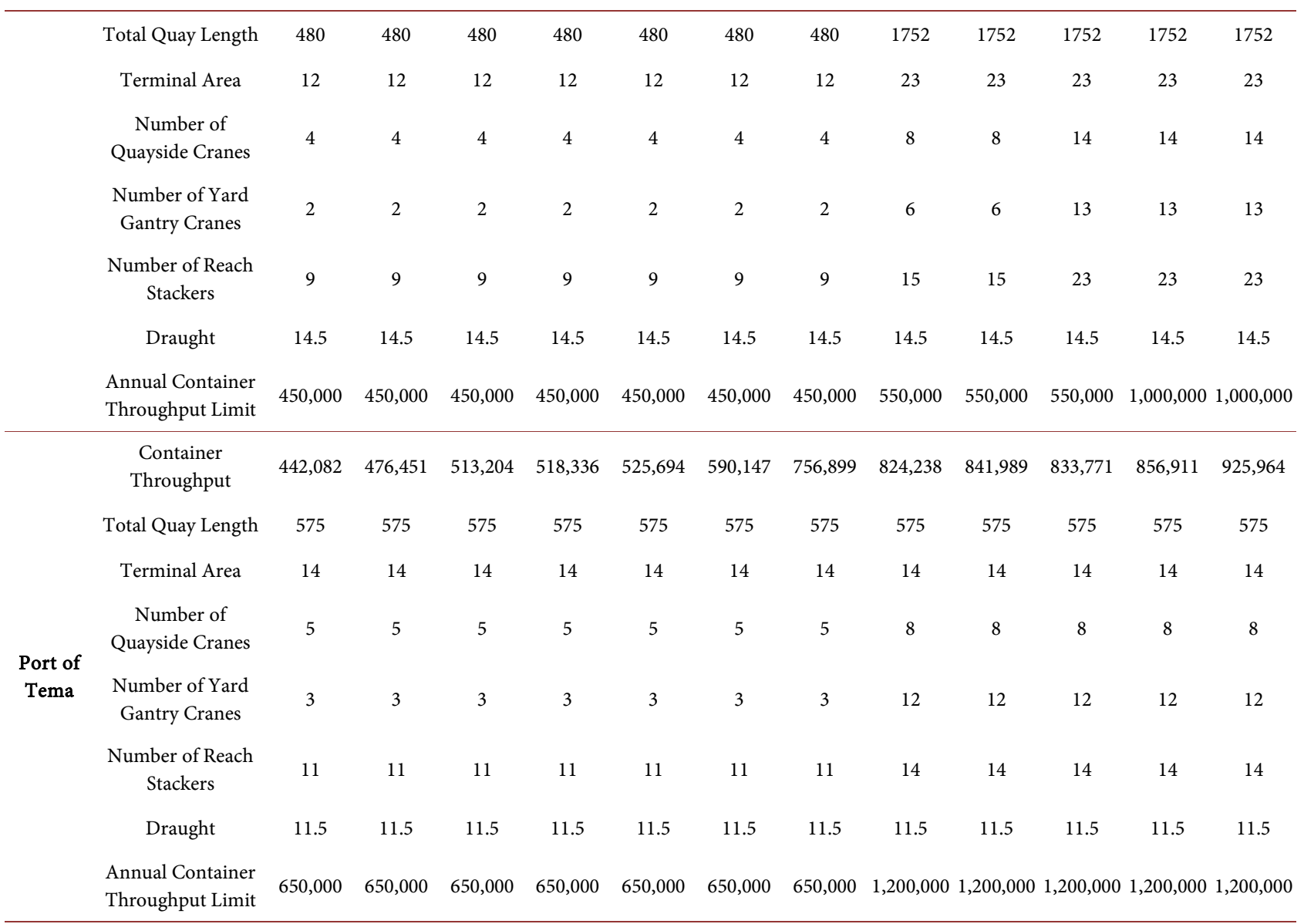

Source: Port Management Association of West \& Central Africa (2017).

Appendix 2: Container Throughput for Selected Countries Ports from Year 2005-2016

\begin{tabular}{ccccccccccccc}
\hline \multirow{2}{*}{ Ports } & \multicolumn{10}{c}{ Year } \\
\cline { 2 - 13 } & $\mathbf{2 0 0 5}$ & $\mathbf{2 0 0 6}$ & $\mathbf{2 0 0 7}$ & $\mathbf{2 0 0 8}$ & $\mathbf{2 0 0 9}$ & $\mathbf{2 0 1 0}$ & $\mathbf{2 0 1 1}$ & $\mathbf{2 0 1 2}$ & $\mathbf{2 0 1 3}$ & $\mathbf{2 0 1 4}$ & $\mathbf{2 0 1 5}$ & $\mathbf{2 0 1 6}$ \\
\hline Port of Abidjan & 710.0 & 507.1 & 469.2 & 652.3 & 610.1 & 561.5 & 546.4 & 633.9 & 745.1 & 783.1 & 835.3 & 705.0 \\
Port of Cotonou & 158.2 & 145.2 & 163.2 & 193.7 & 272.8 & 316.7 & 334.7 & 348.1 & 388.3 & 408.1 & 472.1 & 333.0 \\
Port of Lagos & 870.0 & 875.0 & 903.5 & 947.4 & 710.8 & 1128.1 & 1413.2 & 1623.1 & 1010.8 & 1062.3 & 1156.2 & 1335.4 \\
Port of Lome & 204.6 & 215.8 & 237.8 & 296.1 & 354.4 & 339.8 & 352.6 & 288.4 & 311.4 & 380.7 & 905.7 & 821.6 \\
Port of Tema & 442.0 & 476.4 & 513.2 & 518.3 & 525.6 & 590.1 & 756.8 & 824.2 & 841.9 & 833.7 & 856.9 & 925.9 \\
\hline
\end{tabular}

Source: Container Port traffic, World Bank, (2017). 